\title{
The Politics of Metaphor in Heaney's Sweeney Astray
}

\section{Heaney's Sweeney: Sweeney Astray and the notebook draft}

Seamus Heaney began translating the Middle Irish romance Buile Suibhne after moving south to Wicklow to work on his poetry full-time, in the summer of $1972 .{ }^{1}$ Forty or so pages into the notebook in which the project was first drafted, along the top of a page of miscellaneous notes, Heaney wrote in sprawling, green-ink capitals:

\section{LEFT ULSTER MYSELF / ALLEGORY. ${ }^{2}$}

These words lend credence to the commonly-held view, partly promulgated by Heaney himself, that the story's protagonist - Suibhne, a king of Ulster driven mad during battle and transformed into a bird, who travels throughout Ireland reciting verses about his plight - first appealed to Heaney as an alter ego of sorts. Which elements of Suibhne's case most struck a chord, however, is debatable. Sweeney's defiant reappearance in the 'Sweeney Redivivus' section of Station Island the year after Heaney's 'version from the Irish', Sweeney Astray, was published in 1983, suggests that the figure appealed to Heaney as a symbol of release from social and political obligations. Heaney's claim in an interview of 2002 that Sweeney Astray came about because he 'wanted an excuse to write about rain, wet, woods and trees' points, further, to a desire to frame his translation of Buile Suibhne as not only the story of a figure freed from political ties, but itself a retreat from politics. ${ }^{3}$ Much in Heaney's early draft, however, and his running commentary on it, suggests an urge to contribute to wider political debate, and consider the political implications of writing poetry.

The next page of the notebook elaborates on Heaney's view of Sweeney's significance in three paragraphs, the first visibly revised several times:

$$
\text { the snarl }
$$

a

Sweeney is at once the fallen establishment tormented with hindsight and the suspicious baying resourcefut implacable whinge of the downtrodden, 
tempered by whipped in by anger

kick

sniffing familiars of the boet in the face.

He is Lear and Poor Tom. He is a Brookeborough

and a Bernadette. ${ }^{4}$

The metaphors are wide-ranging, but carefully paired to suggest both conflict and common ground: Heaney's opposed 'fallen establishment' and 'downtrodden' are linked by canine terms; Lear and Poor Tom represent opposite social poles, but are united during the storm; Brookeborough, one of Northern Ireland's most vociferously antiCatholic Unionist prime ministers, and Bernadette Devlin, a prominent student activist in the late 1960s civil rights movement and later a Westminster MP, have names that alliterate, though polar political views. Linking Sweeney to all of these figures brings to mind multiplicity and contradiction as much as characteristics shared.

Towards the end of the notebook, Heaney returns to this theme:

Sweeney is at once Lear and Poor Tom [...] He is paranoiac and schizophrenic. In one way he completely possesses the landscapes he inhabits, in another way he defines himself against them. He is a prism to refract many aspects of the Ulster experience.

Very little of all this makes it into the introduction to Sweeney Astray, published ten years later. Only a passing reference to 'Edgar's jabbering masquerade as poor Tom [sic] itself an interesting parallel to Sweeney's condition' remains, and the oppositions disappear. ${ }^{5}$ But it offers a possible explanation both for Heaney's initial attraction to the figure of Sweeney and for the relatively muted reception of Sweeney Astray. Heaney's suggestive 'prism' metaphor pinpoints precisely what makes Suibhne/Sweeney such a difficult subject: this mad bird-king-poet has, perhaps, the potential to refract too many 'aspects of the Ulster experience'.

In a 1979 article about the role of myth in establishing 'the watermarks that characterise our national soul', Dennis O’Driscoll suggests that Suibhne 'finds his way into modern Irish poetry, as most traditional motifs do, because of his relevance to contemporary struggles rather than out of deliberate piety towards the past'. ${ }^{6}$ But there are many ways in which Suibhne might be considered 'relevant' to contemporary struggles. For Robert Graves, whose White Goddess incorporates the 'tale' of 'Suibne Geilt', he is 'a symbol of 
the poet's plight in a society where art is judged inconsequential and the artist ridiculous'. The Field Day Anthology of Irish Writing describes 'the Sweeney legend' as 'one of the great formulations of the plight of the artist who earns his gift at the cost of alienation and dispossession', and quotes Graves's assessment of it as 'the most ruthless and bitter description in all European literature of an obsessed poet's predicament'. $\mathrm{A}$ reference to the story in the early Irish Book of Aicill, however, focuses on a more redemptive aspect: 'Suibhne Geilt having become mad is not a reason why the battle is a triumph, but it is because of the stories and poems he left after him in Ireland'. ${ }^{9}$ On this reading, poetry is something to be celebrated, and Suibhne's verses restore poetry's standing, rather than merely lamenting its marginal status.

In the published introduction to Sweeney Astray, Heaney offers a motivation for the work that recalls his well-documented preoccupation with the poet's aesthetic and moral responsibilities:

insofar as Sweeney is also a figure of the artist, displaced, guilty, assuaging himself by his utterance, it is possible to read the work as an aspect of the quarrel between free creative imagination and the constraints of religious, political and domestic obligation. (p.viii)

This description clearly resonated with contemporary reviewers: John Carey and Blake Morrison both paraphrased it, echoing and slightly altering Heaney's phrasing; and Ciaran Carson's review in The Honest Ulsterman quoted the passage in full. ${ }^{10}$ An expanded version of Carson's review published the following year quotes 'a figure of the artist, displaced, guilty, assuaging himself by his utterance' twice - though the first crucially misquotes the line as 'assuaging himself of his utterance' (my emphasis) - and ends with the suggestion that Sweeney Astray might be 'an attempt to assuage another kind of guilt, that of not belonging fully to a linguistic community.' ${ }^{11}$ The basis for this reading seems to be Carson's concern in this piece with the status of the Irish language in general, more than anything in Heaney's translation; but the way that it draws on Heaney's own phrasing highlights strikingly just how pervasive his words were. They have been quoted many times since; ${ }^{12}$ as has so often happened, Heaney's own commentary quietly yet persuasively penetrated the wider critical discourse. The sentence that follows in Heaney's introduction to Sweeney Astray, however, is less commonly quoted: 
It is equally possible, in a more opportunistic spirit, to dwell upon Sweeney's easy sense of cultural affinity with both Western Scotland and Southern Ireland as exemplary for all men and women in contemporary Ulster [...]. (pp. vii-viii)

Although presented as something of an afterthought, the phrase 'exemplary for all men and women in contemporary Ulster' has an uncharacteristically heavy-handed ring to it. It is difficult to imagine Sweeney as a figure both 'exemplary' in his 'easy cultural affinity' and simultaneously 'displaced' and 'guilty'.

Heaney himself draws back from this possible 'significance', continuing: 'But the work makes its immediate claims more by its local power to affect us than by any general implications we may discover in its pattern' (p. viii). This is perhaps a salutary warning against searching too concertedly for a broader allegorical application; but a connection between the 'general' and the 'local' does exist, and it is particularly apparent in the relations between local linguistic metaphors in the text and what might be considered its overarching metaphorical significance. Early reviewers of Sweeney Astray had their reservations about it: John Montague wrote in Fortnight that, although Heaney had 'striven manfully to remind us of an early Irish masterpiece', he seemed not to possess 'the crucial gift or wound of a grafted tongue'; ${ }^{13}$ Eavan Boland ventured in the Irish Times that 'if anything mars this otherwise fine sequence by Seamus Heaney it is the selfconsciousness', and puts forward the 'cavil' that Sweeney is 'presented all the time in a densely literary way'; ${ }^{14}$ and Denis Donoghue's review reported an 'impression' that Heaney found Buile Suibhne 'line by line, hard to deal with'. ${ }^{15}$ But it may well be that all of these concerns, apparently about the linguistic process of translation, stem more from the difficulty of developing and sustaining artistic control of the various different positions Sweeney can represent. The metaphors of both the early notebook draft and the published Sweeney Astray expose unresolved tensions in the depiction of Sweeney, and hint at the possibility that the 'schizophrenia' Heaney referred to in the notebook lies as much in his own efforts to paint Sweeney as in the finally realized character. In what follows, I will consider how the metaphorical texture of Heaney's translations mirrors the ambivalence of his commentary on them, publically and in the notebook draft. 


\section{II. 'First time around': Translating Buile Suibbne}

Heaney's 1989 essay 'Earning a Rhyme: Notes on Translating Buile Suibhne' begins somewhat circumspectly, describing the atmosphere in Northern Ireland in the late 1960s and early 1970s, when poets 'who had ignored their different religio-political origins in the name of that greater humility and flexibility which the imaginative endeavour entails' found themselves 'tugged' by 'pleas for identification with the political aims of their groups'. 'In the anxiety of those times,' Heaney asserts, 'the abiding problem was to discover a properly literary activity which might contain a potentially public meaning. ${ }^{16}$ He then situates his work in this setting, with increasing momentum:

What had the tale of a petty king from seventh-century Ulster, [...] what had all this amalgam in verse and prose to do with me or the moment? How could a text engendered within the Gaelic order of medieval Ireland speak to a modern Ulster audience riven by divisions resulting from the final destruction of that order? [...] What had the translation of the tale of a Celtic wild man to do with the devastations of the new wild men of the Provisional IRA?

The questions sound increasingly rhetorical, but an answer is offered, cautiously phrased:

My hope was that that book might render a Unionist audience more pervious to the notion that Ulster was Irish, without coercing them out of their cherished conviction that it was British. [...] I hoped the book might complicate the sense of entitlement to the land of Ulster which had developed so overbearingly in the Protestant majority [...]. I wanted to deliver a work of imagination that could be read universally as the thing-initself but which would also sustain those extensions of meaning that our disastrously complicated predicament at home made both urgent and desirable.

The aim, then, was to produce a work that might engage indirectly in contemporary politics, without compromising its literary status as 'the thing-in-itself. Crucially, though, Heaney is here describing his motivations 'First time around', when first translating Buile Suibhne, ten years before Sweeney Astray was published, and nearly twenty years before the essay was written. To the Heaney of 'Earning a Rhyme' looking back, that first, unpublished, version took liberties: 
First time around, I was far more arrogant in my treatment of the verse. That is to say, I arrogated to myself the right to follow suggestions in the original, to develop a line of association out of the given elements of the Irish rather than to set down an obedient equivalent. I allowed myself to import echoes from the English literary tradition, from the Bible, to perform in metaphor what the text delivered in statement. [...] Lowell's example was operative here. His trick of heightening the sense by adding voltage to the diction and planting new metaphors into the circuit was not lost on me. ${ }^{18}$

This method of 'importing echoes' is certainly evident in the notebook draft - in the Yeatsian lines 'I am as mad as the mist and snow' and 'But all's changed, changed utterly', for example, both of which Heaney ultimately cut. ${ }^{19}$ And he clearly experimented with 'planting' new allusive metaphors: in verses describing Sweeney's yearning to be home which the later published version skips altogether, for instance, the notebook draft included the line 'I'm no happy shepherd / or passionate pilgrim', modifying it to 'I'm no passionate pilgrim wild rover or passionate pilgrim' - vacillating between the English literary tradition and Irish folksong - before abandoning it altogether. The Sweeney of the early draft is a conductor (to pursue the electricity metaphor) of other associations as much as a character in his own right.

The notebook is full of other such metaphorical identifications which do not make it into Sweeney Astray, but hint at Heaney's urge to define Sweeney, an impression further reinforced by a list below 'LEFT ULSTER MYSELF / ALLEGORY' in the notebook:

\section{GUERILLA / TRUCE BREAKER \\ TONGUE OF THE LANDSCAPE \\ SURVIVOR OF WAR, AS VICTIM.}

The first verse of Section 69, which witnesses Suibhne wretched and alone but for 'the soughing of the rude gale', as O'Keeffe translates it, ${ }^{20}$ is transformed in Heaney's first draft by a string of nominal metaphors found in neither O'Keeffe nor the original:

I am Sweeney, beggar in death's door, outcast from life's feast a scarecrow, a buffeted vane. 
The inspiration for the scarecrow and weathervane is surely O'Keeffe's 'rude gale', but the nominal form of the metaphors intensifies the sense that, in describing Sweeney's reflections on his status, Heaney, too, is trying to establish his Sweeney's identity. ${ }^{21}$

In 'Earning a Rhyme', Heaney quotes a handful of verses from his first attempt to translate Buile Suibhne in 1972/3 that show the degree to which he coloured the original with metaphors of his own. O'Keeffe's somewhat pedestrian:

Though I be as I am tonight, there was a time when my strength was not feeble over a land that was not bad' (p.27)

is transformed, for instance, into what Heaney calls 'a more jacked-up performance altogether':

\author{
Though I am Lazarus, \\ There was a time \\ When I dressed in purple \\ And they fed from my hand. ${ }^{22}$
}

The next stanza develops a metaphor out of O'Keeffe's 'On splendid steeds' - 'the world / Was the bit in my horse's mouth' - and adds an entirely new one: 'the tide of my affairs was rising'. No holds are barred in this version's metaphors.

But in 1979, whilst at Harvard, Heaney 'suddenly started one morning to reshape stanzas from scratch', and discovered that 'closer inspection of the thickets of the Irish' led to 'a different kind of engagement'. The essay concludes:

The closer, line by line, stanza by stanza, end-stopped, obedient, literal approach finally yielded more. One had a sense of accumulation rather than of truancy [...]. One also had forgotten about the political extensions that were originally intended $[\ldots]$ and valued more the defined otherness of Buile Suibhne as art. ${ }^{23}$

There is something unconvincing about this impersonal 'one' having 'forgotten about' the political extensions, but the position adopted here is clear: the first draft, with its 'heightening' metaphors, was less successful than the more faithful 'literal approach' Heaney eventually settled upon. And yet many of the ' $\mathrm{X}$ is $\mathrm{Y}$ ' metaphors of the early draft, which elaborate on the original and O'Keeffe's staid translation of it, are kept in Sweeney Astray, suggesting that Heaney's later attempts were not as 'literal' - non- 
figurative, faithful to the original - as this would suggest. In Section 26, for instance, in both the notebook draft and Sweeney Astray, O'Keeffe's syntactically faithful but longwinded 'for it is there stood his fortress and his dwelling-place' (p.37) becomes, pithily, 'That was his ark and his Eden', adopting Biblical metaphors. And when Sweeney recalls the leaping contest with Lynchseachan's hag, whilst the original Irish text sees him catalogue all the places in Ireland they passed through without him managing to 'elude' her (an opportunity to emphasize Sweeney's 'easy sense of cultural affinity' with the whole of Ireland), Heaney opts instead for a strikingly nominal approach for which there is no basis in the original or O'Keeffe:

I was the wind and she was smoke.

I was the prow and she the wake.

I was the earth and she the moon (p.67).

These formulations suggest a symbiosis absent from the original, and the explicitly figurative perspective changes its tone: in uttering them, Sweeney is afforded a more reflective, or poetic, persona. These metaphors are hardly 'an obedient equivalent'. What, then, might the metaphors of Sweeney Astray, underplayed in Heaney's own account of his encounter with Buile Suibhne, contribute to a critical reading of the text?

\section{Metaphor and wordplay in Buile Suibbne and Sweeney Astray}

Commenting on the 'dense, riddling effect appropriate to Sweeney's state of mind' of Buile Suibhne's dependence on words with multiple meanings, Ciaran Carson writes: 'I do not know if we can call this usage metaphorical; it is, rather, exploitative, the words themselves generating implicit lines of inquiry'. ${ }^{24}$ Carson clearly uses 'exploitative' here to imply the kind of opportunism allowed by linguistic ambiguity, in contrast to the deliberate shift metaphor involves, using one word instead of another; but it is a suggestive term to use. In Sweeney Astray, certainly, secondary associations of words with many meanings often surface troublingly, and belie Heaney's assertion that the 'political extensions' had been 'forgotten'. Heaney's 'plantation' (p.18) for O'Keeffe's 'densesheltering wood' (p.15), for instance, cannot but seem loaded, especially in light of Heaney's claim that he first translated Buile Suibhne in the hope that it might 'complicate 
the sense of entitlement to the land of Ulster' felt by the Protestant majority. ${ }^{25}$ Other such politically-loaded words follow: Sweeney sees himself as an 'outcast' (p.23, p.54), and describes himself as the cleric Ronan's 'victim' (p.70), for instance, while Ronan sees Sweeney's fate as 'an example, a warning' (p.64). Perhaps the most striking features in Heaney's Sweeney's rebuke of the woman who has - unwittingly - taken watercress from his favoured patch: 'Let thieving make a scapegoat of you' (p.49). For seasoned readers of Heaney's poetry, the word 'scapegoat' must surely bring to mind the body controversially eulogized in North's 'Punishment' (1975). (In the notebook draft, this line reads 'I'll have you for my scapegoat', which is even more powerfully reminiscent of the lines from 'Punishment'.) Outcast, example, victim, scapegoat: these are all words that must take on a special significance in the context of the Troubles, in what Heaney described in 'Earning a Rhyme' as 'the anxiety of those times'. The politics is still evident, if not so explicit, in the language of Sweeney Astray.

Carson focuses on less politically-loaded double meanings. A striking example in the original involves the Irish word 'beann' (and its various forms - beinne, binne, beinn) which can mean (amongst other things) the peak of a mountain, an antler or the tip of a weapon, and is used repeatedly in Section 40, in Suibhne's verses considering his relationship to nature. O'Keeffe registers this in his notes, concluding that 'there is evidently a play intended on the word', though he finds it 'difficult to grasp the significance' (p.169). His effort to reproduce the effect with the word 'point', which covers many of the meanings of the Irish word, leaves him with the nonsensical lines 'If I were on each little point, / there would be a pointlet on every point' (p.81). Carson acknowledges the difficulty of trying to replicate the intricacies of the Irish verse, but is confident of the original's meaning:

What the Irish implies, by its play on the subjunctive verb 'to be' (da mbeinn), is that the physical world of antlers, mountain-peaks, spears, has become microscopically internalized in a kind of Third Policeman logic. ${ }^{26}$

Heaney avoids the play on 'points', ${ }^{27}$ but his translation - 'I would roost among / her mazy antlers' (p.45) - links Sweeney and his environment to similar effect. He frequently equates Sweeney figuratively with elements of his surroundings in this way, as if to suggest that the boundaries between Sweeney's mental processes and physical condition are porous. When Suibhne returns to visit his wife Eorann, O'Keeffe's physical description hints at Suibhne's feelings - 'warm for thee on the down of a pleasant bed, / 
cold for me abroad till morn' (p.47) - but Heaney draws on the same resources to develop a more directly accusatory figurative tone: 'But you have broken trust, / unmade it like a bed - / not mine in the dawn frost / but yours, that he invaded' (p.31). In O'Keeffe's version, as Suibhne bemoans the hardship he faces, the physical environment works against him:

Frosty wind tearing me,

Already snow has wounded me,

The storm bearing me to death

From the branches of each tree (p.31).

Heaney, however, goes further and has Sweeney imagine himself figuratively as like a tree in a storm:

wind-scourged, stripped

like a winter tree

clad in black frost

and frozen snow (p.24).

Though O'Keeffe is closer to the wording of the original, Heaney's version more closely reflects the way its formal qualities influence the sense: 'éccuibh' (death, or hardship) is rhymed with 'géccuibb' (branches, or boughs), again tying Sweeney to his surroundings. Descriptions literal in the Irish - Suibhne in a tree, buffeted by the storm - use rhyme, or alliteration, to hint at a psychological dimension; Heaney develops literal descriptions of the environment into metaphors (and similes) to convey Sweeney's mental state.

Carson objects to Heaney's use of free verse for 'the more heightened prose passages' of the Irish: the carefully judged alternation between verse and prose in Buile Suibhne, Carson explains, marks a division between 'the outward events of the story' and the 'inward, psychological journey' Suibhne undergoes, which is disrupted by Heaney's rendering of narrative prose as verse. ${ }^{28}$ Denell Downum expands on this point, writing of Sweeney's 'battlefield seizure': 'To modern readers steeped in twentieth-century psychology, this passage may appear to be of primarily internal, psychical interest; in Carson's schema it would belong in verse' - as in Heaney's version. But, Downum argues, the fact that this passage is in prose in the original emphasizes 'the outward and social aspects of the calamity that befalls King Sweeney', and 'the social significance of his disenfranchisement'. ${ }^{29}$ These critics are right to emphasize the 'creative interplay' between verse and prose in the original. Trevor Joyce's much looser 'inventive' 
translation of Buile Suibhne is also alert to this distinction: his separation of verse and prose, presenting a full prose account before an uninterrupted series of lyrics in Sweeney's voice, has the effect of alienating and so intensifying it, to powerful effect. ${ }^{30}$ But the kind of 'internalizing' of nature that Carson sees in Suibhne's famous verses about the trees, ${ }^{31}$ which contrasts with the 'external' perspective of the prose, is conjured in Sweeney Astray through Heaney's development of metaphors for Sweeney's state of mind drawing on his environment.

Heaney's figuratively-mediated psychologizing of Sweeney, however, presents aesthetic difficulties. O'Keeffe's Suibhne begins and ends his poem of Section 40 with the same words - a device frequently employed in Buile Suibhne - addressing a stag: ' $\mathrm{O}$ little stag, (thou) little bleating one, / O melodious little clamourer'. Heaney's enacts a surprising shift: in both the notebook draft and Sweeney Astray, Sweeney goes from observing the 'little timorous stag' (p.39) to identifying himself with it: 'I am a timorous stag, / feathered by Ronan Finn' (p.46). Perhaps Heaney means to highlight Sweeney's 'schizophrenia', through his too-ready identification with his environment. But this 'feathered' bird-man's description of himself as a stag risks metaphorical overload. And this is not the only such mixed metaphorical identification: midway through the section, Sweeney proclaims 'If I show my heels / I am hobbled by guilt. / I am a sheep / without a fold' (p.44). The attention to his heels, even figuratively, jars against the image of Sweeney as bird, as does the description of Glen Bolcain as somewhere he can 'go to ground' (p.27). Perhaps these are conscious demonstrations of Sweeney's fractured personality, rather than a failure in figurative cohesion; either way, it is disconcerting.

\section{Sweeney as bird-man}

The tension between figuration and what we might call psychological realism in Sweeney Astray is most evident when Heaney introduces bird-related metaphors using language offered by the literal setting of the original. Beyond the most explicit ' $\mathrm{X}$ is $\mathrm{Y}$ ' formulations, it can be difficult to decide what is metaphorical in literary contexts - that is, which aspects of a narrative should be read as standing, metaphorically, for something else, and what merely describes what it claims to. In Buile Suibhne, this is complicated by the quasi-mythical setting: the representation of Sweeney as poet-king, part-man, partbird, fluctuates exhilaratingly, but unsettlingly, between the realistic and the fantastical, 
with moments of genuine psychological poignancy and moving poetry emerging from the otherwise improbable portrayal of a figure who leaps through trees across Ireland.

Even in the Irish, it is never entirely clear whether Suibhne is supposed actually to have become a bird, or merely in his madness thinks so. Both psychological and supernatural explanations for the transformation are provided: Ronan's curse condemns him to a life of exile, but it is amidst the clamour of battle that Suibhne is afflicted. The prominence of the ambiguous word 'astray' in Heaney's version compounds this uncertainty, suggesting a loss of direction both physical and (figuratively) moral. Denis Donoghue objects to Heaney's choice of 'astray' for the title, which he feels lacks the force conveyed by O'Keeffe's 'frenzy', and recollects that 'In the north [...] we said that someone was "astray in the head", meaning daft or simple-minded: not the same ailment'..$^{32}$ But Heaney's 'astray' captures brilliantly the ambiguity of whether Sweeney's affliction is mental or physical: the lines 'I am astray in the head, / astray over the land' in the notebook draft, for instance, render the mental/physical duality more pronounced than anywhere in the original, O'Keeffe or the published Sweeney Astray.

Most commentators agree that between the tale's first telling and the earliest extant manuscript the influence of the Christian tradition probably changed the motive for Suibhne's madness from the chaos of battle to the cleric's curse. ${ }^{33}$ Investigating the word 'geilt' (used to describe Suibhne in the original, and translated by O'Keeffe and Heaney as 'madman'), Nora K. Chadwick argued in 1942 that the account of Suibhne's madness, or geltact, derives from another Middle Irish text, and that the 'supernatural element' of Buile Suibhne was 'doubtless no part of the original story', but the result of its author interpreting the figurative language of his source literally. ${ }^{34}$ This offers an intriguing parallel to my contention that Heaney renders the literal language of Buile Suibhne more figurative.

Descriptions of Suibhne in the Irish are ambiguous enough to leave open to interpretation whether his transformation is literal or figurative. O'Keeffe seems unwilling to commit to the mythical dimension of the tale: his footnote to 'though my talons to-night are feeble' observes in oddly guarded terms that 'throughout the story [Suibhne] speaks as though he imagined himself a bird' (p.33) - implying that O'Keeffe might not. He highlights the improbability of the movement of Domnall's army, as if in an effort to establish geographical accuracy, but exempts Suibhne, again in curiously noncommittal fashion: 'Whatever we may think of Suibhne, it is scarcely likely that Domnall and his army went so far afield after the battle' (p.162). Irish mythology is full of human- 
bird transformations, but Suibhne/Sweeney provides a particularly striking example in that his versifying gives him a very human voice, and his sufferings are presented in a very physical way. ${ }^{35}$ The poignancy of his situation - which Heaney was clearly drawn to - is compromised by the difficulty of relating to a figure part mythological and part psychologically compelling; the difficulty of picturing him distracts from the intensity of Sweeney's plight.

The problem of deciding - line by line, as well as overall - whether to describe Sweeney as a bird or merely as like one may be partly responsible for Denis Donoghue's impression that Heaney found Buile Suibhne 'hard to deal with'. O'Keeffe describes the moment when Ronan's curse comes to fruition as follows: 'he went, like any bird of the air, in madness and imbecility' (p.15). The same phrase, 'like any bird of the air', is later used by Loingseachan to describe Suibhne's plight (p.53). This 'any' ('gach' in the Irish) leaves the extent of his transformation ambiguous. Heaney's version is less equivocal: 'he levitated in a frantic, cumbersome motion, like a bird in the air' (p.18) - not a bird, but merely like one. The elaboration of 'went' to 'levitated, in a cumbersome, frantic motion' is also significant, because, of course, levitating for most birds is not 'cumbersome': this is a man imitating the movements of a bird. Donoghue declares, without mincing his words: 'I don't see where Heaney has found the frantic cumbersome motion. It is neither in the Irish nor in ornithology. ${ }^{36}$ It is not in the Irish, certainly - this is one of Heaney's more creative translations - but the point here is surely that Sweeney movement is awkward precisely because he is not an archetypally graceful bird, but a human figure struggling with a painful transformation.

John Kerrigan's analysis of this passage returns to the delicately-poised tension between the mental and physical in Heaney's portrayal of Sweeney: 'when Sweeney translated is translated into a bird', he suggests, Heaney 'gets inside transformation'; 'the words used to draw Sweeney from the mental to the physical $[\ldots]$ tap into the reader's nervous system, ${ }^{37}$ But the 1972/3 notebook draft suggests that Heaney had difficulty presenting this transformation. Above these verses in the notebook is written 'VERBS SUGGESTIVE OF THE METAMORPHOSES'. Heaney tried out various possibilities for these lines:

His fingers stiffened like giblets his feet were a flurry and scuffled and flurried his heart beat like a startled wren's [...] And he levitated 
and wobbled in a frantic wobble

like any some cumbersome rare wild fowl of the air bat out of hell

'Bat out of hell', in a different colour pen, was clearly added later. Once again, the very natural difficulty of imagining Sweeney as a bird-man becomes entangled in the literary dilemma of how to depict this character, which might be at once victim and aggressor, 'a Brookeborough and a Bernadette', 'Lear and Poor Tom', and even Heaney himself, and might prove 'exemplary' to contemporary Ulster, whilst maintaining its own integrity.

Buile Suibhne and O'Keeffe's translation betray little unease about the physical particulars of Suibhne's state: verbs usually used of human movement describe his otherwise bird-like actions. Heaney, by contrast, opts for terms that apply literally to birds but only metaphorically to humans. For O'Keeffe's madman 'going into the tree' (p.17; 'ag dol, the verb to go, in Irish), Heaney has 'lighting', in both Sweeney Astray (p.19) and the notebook draft; and where in O'Keeffe 'the madman sat down upon the lintel of the hut' (p.45), Heaney uses the more bird-appropriate verb 'to land' in Sweeney Astray (p.31; the notebook skips this section). Bird verbs abound in Sweeney Astray - 'launched', 'flew', 'perched', 'skimmed over' - but almost all can be used figuratively of people, too. Some, though, are graphic enough to threaten our suspension of disbelief: in Section 17, for instance, Sweeney's movements are described in vivid detail, with some verbs clearly more suited to man than bird - 'shouldering through ivy bushes', 'trekking through glens' (p.21). These kinds of tension might reflect Sweeney's discomfort during a gradual process of mental and physical transformation, but draw attention to a difficulty arguably better glossed over.

Elsewhere, though, Heaney's recourse to bird-related verbs leads, paradoxically, to descriptions more poignantly human. Immediately before his violent fall, Sweeney Astray sees Sweeney 'cooped up' (p.21) in a hawthorn tree, where in the Irish and O'Keeffe he just 'happened one night to be' there (p.23). 'Cooped up' is, figuratively, vividly expressive of human claustrophobia; using a word entirely appropriate in an avian context, Heaney encourages us to relate to Sweeney as a human figure. Heaney repeatedly makes the most of such opportunities to slip in bird metaphors: O'Keeffe's slightly turgid 'desire for every place which he had not reached' (p.15) becomes, more poetically, in Sweeney Astray, 'dreamed strange migrations' (p.18); and O'Keeffe's 'long step' (p.121) becomes 'a tough migration' (p.63). Some are more tongue-in-cheek: Moling's observation 'O mad one, that is early eating' (p.137) triggers, irresistibly, in Sweeney Astray, 'Aren't you the early bird?' (p.70), affecting the tone of the passage. But 
many of Heaney's bird metaphors are subtle and moving. O'Keeffe's 'Ronan does not allow me to trust you' (p.43) becomes, in Sweeney Astray, with an obvious pun but surprisingly touchingly, 'Ronan has left me with the fears of a bird' (p.30). When, after seven years of wandering, Suibhne/Sweeney goes to visit his wife, O'Keeffe's simply says 'long have I been restless' (p.47), but Heaney's hovers 'Restless as wingbeats / of memory' (p.31) above her bed. Her response - 'I wish we could fly away together, / be rolling stones, / birds of a feather' (p.32) - verges on bathos in its recourse to very conventional metaphors, and is perhaps meant to suggest insincerity; Denis Donoghue thinks so, suggesting that Sweeney's 'faithless' wife 'sweet-talks' with these words. But as Donoghue also observes - the continuation of her speech, 'I'd swoop to pleasure you in flight / and huddle close on the roost at night' (p.32), is unexpectedly beautiful.

As the tale draws to a close, and Moling speaks beside Suibhne's tomb, Heaney builds on O’Keeffe's 'long shall I keep his memory in my breast' (p.157):

His memory flutters in my breast.

His soul roosts in the tree of love.

His body sinks in its clay nest (p.76).

The question with such explicit metaphors is whether their prominence diminishes the scene's affective power. While the 'fluttering' memory is kinesically evocative, 'the tree of love' sounds clichéd, and 'clay nest' tries perhaps too hard to fit the conceit. Time and again, Heaney faces the problem of how far to exploit the rich potential for metaphor, without compromising the tale's otherwise powerful potential for psychological realism.

Of course, Suibhne's relationship with his surroundings is complicated and ambivalent in all versions. The hawthorn 'piercing and rending his side' (p.23) causes O'Keeffe's Suibhne to reflect that 'it is hard to endure this life after a pleasant one' (p.25); but, hearing the vesper-bell, he claims that 'the cooing of the cuckoo of the Bann' is 'sweeter' (p.33). His reverential apostrophe to the trees exposes a sinister side: the alder and birch are 'delightful' (p.65, 67), and the holly is 'sheltering' (p.67), but the briar 'ceasest not to tear me, / till thou hast thy fill of blood' (p.65), and the ash-tree, 'handweapon of a warrior', is 'baleful' (p.67). Heaney seizes on this dark turn: in Sweeney Astray, 'scarlet berries clot like blood / on mountain rowan', and the briars, invested with malevolent agency, 'draw blood and curl up innocent / to sneak the next attack' (p.40). Suibhne/Sweeney belongs nowhere: he is at home neither in the wild nor amongst 
people. Heaney claimed in the introduction to Sweeney Astray that 'the green spirit of the hedges embodied in Sweeney' was one of the things that drew him to Buile Suibhne, and the Sweeney of Station Island paints him as a symbol of artistic freedom; but he is still also, inescapably, that 'figure of the artist, displaced, guilty, assuaging himself by his utterance'.

When Ronan first curses Suibhne, he proclaims he will be 'aon re henaibh', which O'Keeffe translates as 'one with the birds' (p.13), but which Heaney renders pejoratively, in an oddly flippant phrase, as 'bird-brain among branches' (p.17). (In the notebook draft, this is 'a swinger through trees, a bird brain', which sounds even odder.) When Suibhne later recalls this scene, he reports Ronan's words as 'Thou hast leave / to go with the birds' (p.43); this time, Heaney interprets it more positively as 'Let the freedom of the birds be yours!' (p.30). In the notebook draft, the wording is more graphic, and negative:

\author{
spet \\ he yelped spat like a shitting bird \\ his the holy word bad-tempered \\ fell struck like shit from a bird \\ and that sent me like shit off a shovel \\ above all \\ expectation. \\ I soared over the nation.
}

The vivid figurative possibilities, tried out on Ronan, Sweeney and 'the holy word', start to spiral out of control.

\title{
V. 'Motives' for translation
}

Asked by an interviewer in 1988, What do you look for in a translation? Authenticity? Clarity?', Heaney proposed a distinction between two kinds of translation, both developed out of 'good motives' but which 'sponsor slightly different procedures'. The 'absolutely pure motive', he explained,

is to so love the work in the first language that you're hurt that it isn't shared in the next language. You will do everything that is possible to bring across the unique and beloved features of the original, and this will involve an attempt at all kinds of precisions, equivalents, and honesties. ${ }^{38}$ 
The second motive is 'impure', according to Heaney, but 'has its own verite. This is 'translation as taking it over', and 'in two senses - in the slightly imperial sense and in the original etymological sense of carrying a thing across', with a suggestive nod towards the etymology of the term 'metaphor'. His translation of the Ugolino episode from Dante's Inferno, Heaney suggests, and - 'to some extent' - his translation of Buile Suibhne, were inspired by the second, 'impure' motive. He was drawn to Dante because of its 'oblique applicability (in its ferocity of emotion and in its narrative about a divided city) to the Northern Irish situation'; of Buile Suibhne, he writes only that it was 'in order to get to know it' that he wanted to 'pull it out of Irish'. 39

A few years earlier, in 'Envies and Identifications: Dante and the Modern Poet', Heaney had written that:

when poets turn to the great masters of the past, they turn to an image of their own creation, one which is likely to be a reflection of their own imaginative needs, their own artistic inclinations and procedures. ${ }^{40}$

Heaney's 'need' in Sweeney Astray seems to be for both a figure of creative liberation and a representative of the state of not belonging; poetry might be a force for good, a guilty evasion or a necessary release. But whilst works of literature often accommodate this kind of ambivalence, translation renders figurative coherence more vulnerable. When Loingseachan announces (falsely) that Suibhne's father is dead, Suibhne's reply is expressed in what O'Keeffe calls a 'curious phrase', the meaning of which 'seems to be' that 'the news of his father's death struck him with horror' (p.167), 'Domgaibh dom formadh on'. O'Keeffe translates this as 'That has seized me' (p.53); Heaney opts for 'That is a seizure' (p.34). For something 'to be a seizure' is not idiomatic, though the ' $\mathrm{X}$ is $\mathrm{Y}$ ' form might lead us to expect it to be. Heaney is channelling a convention apparent in the original of using proverb-style nominal metaphors to describe loss and mourning - in O'Keeffe, 'For a household to be without a wife / is rowing a rudderless boat' (p.55), 'the heart's needle is an only daughter' (p.57) and so on. Heaney's rendering of O'Keeffe's 'whoso is brotherless has a gaping side' (p.55) as 'A dead brother is a wounded side' (p.35) again tries to reproduce this effect; but, like 'to be a seizure', it doesn't quite work. Heaney keeps closest to O'Keeffe's wording here, as if acknowledging that this kind of culturally-conditioned formulation cannot be substituted; but the result is that it sounds odd in English. The metaphors simply don't translate. 
Elsewhere, we find incongruous metaphors of Heaney's own devising. Sweeney Astray's describes Sweeney after falling from the trees as 'on the ground like a man in a bloodbath' (p.21) - where even the 'less obedient' notebook draft has only 'prickled and cut and bleeding all over' - in an unsettling blend of metaphor and simile. These awkward adapted figurative expressions are perhaps partly responsible for the early critics' uncertainty about Heaney's translation, but they are also symptomatic of the work's wider struggle with the competing realistic and figurative, physical and psychological demands of depicting Sweeney. Adapting the now commonplace figurative notion of conflict as 'a bloodbath' to push us towards a more literal reading could be yet another way in which the metaphorical and the literal interact uneasily - and powerfully so - in this story.

Many early reviews of Sweeney Astray took the irresistible title 'Heaney's Sweeney', but it is more than just a serendipitous rhyme: considering what 'Sweeney' represents for Heaney, compared to the 'Suibhne' he found in O'Keeffe's bilingual edition, takes us to the heart of Sweeney Astray as a literary endeavour. The linguistic metaphors which appear line by line within the text play out in miniature the broader conceptual struggles of the work, which finds itself caught between political commentary and literary escape. Denis Donoghue broaches the significance of Northern Irish politics explicitly, by highlighting what he interprets as Heaney's disinclination to: 'Tact prevents him from making anything of the association between Sweeney and himself, two poets driven to fury if not to madness by the horrors of war in the north of Ireland. ${ }^{41}$ Heaney's own commentary gestures towards this association, but the 'tact' Donoghue aptly intuits manifests itself as a kind of ambivalence as to whether Sweeney Astray should operate as a memorial to a little-known text, 'an excuse to write about rain, wet, woods and trees', or as subtle political commentary; and this ambivalence surfaces in the metaphorical texture of the work. We are left with a sense that Sweeney is something between a symbol and a sympathetic human figure. In many ways, of course, this tension aptly reflects the difficulty of the political issues Heaney gestured towards in translating Buile Suibhne. The incongruities of Sweeney Astray's metaphorical make-up might be a symptom of its success in capturing underlying unease during 'the anxiety of those times'. 


\section{Notes}

1. Heaney's source for his translation was J.G. O’Keeffe's 1913 Irish Texts Society Buile Suibhne (The Frensy of Suibhne), a bilingual edition based on a late-seventeenth-century version of the story. Heaney anglicizes 'Suibhne' to 'Sweeney'; throughout this article, I have used whichever form appears in the text under discussion.

2. This notebook is housed in the manuscripts collection of the National Library of Ireland, amongst 'Drafts of "Sweeney Astray", MS 41,932.

3. Talking with Poets, ed. by Harry Thomas (New York: Handsel Books, 2002), pp.58-9.

4. I have tried to reproduce the effect of Heaney's handwritten edits, using the 'strikethrough' function wherever Heaney crossed a word out, and placing words above the main line of type where Heaney, too, added them above his lines, presumably once the words following had already been written.

5. Sweeney Astray: A Version from the Irish (Derry: Field Day, 1983), p.viii. All subsequent references are to this edition.

6. Dennis O'Driscoll, 'Remembering the Past', in The Crane Bag 3.1 (1979), 'The Idea of Tradition', collected in The Crane Bag Book of Irish Studies, ed. by M.P. Hederman and R. Kearney (Dublin: Blackwater Press, 1992), pp.421-3.

7. Robert Graves, The White Goddess (London: Faber and Faber, 1961), p.455.

8. The Field Day Anthology of Irish Writing, Volume 4, ed. by Angela Bourke (Cork: Cork University Press, 2002), pp.226-7. The Graves quotation is from The White Goddess, p.455.

9. This passage is quoted in O'Keeffe's introduction to his Buile Suibhne, p.xvii.

10. John Carey, 'The Joys of Heaney', in The Sunday Times, 14 October 1984; Blake Morrison, 'Encounters with Familiar Ghosts', in the TLS, 19 October 1984, pp.1191-92; and Ciaran Carson, 'Sweeneys Ancient and Modern', in The Honest Ulsterman 76 (Autumn): 73-9, p.77.

11. Carson, 'Sweeney Astray: Escaping from Limbo', in The Art of Seamus Heaney, ed. by Tony Curtis (2nd edn, 1985), p.147.

12. See, for instance, Rebecca Solnit's A Book of Migrations: Some Passages in Ireland (London: Verso, 1997), p.134; Denell Downum’s ‘Sweeney Astray: The Other in Oneself, Eire-Ireland 44.3-4 (2009), 75-93 (p.83); and the introduction to The Cambridge Companion to Seamus Heaney, ed. by Bernard O'Donoghue (Cambridge: Cambridge University Press, 2008), p.8. 
13. John Montague, 'Tarzan among the Nightingales', Fortnight 200 (1983), p.27.

14. Eavan Boland, 'Heaney's Sweeney', The Irish Times, 10 December 1983.

15. Denis Donoghue, 'A Mad Muse - Sweeney Astray: A Version from the Irish by Seamus Heaney', New Republic, 30 April 1984, p.28.

16. Seamus Heaney, 'Earning a Rhyme: Notes on Translating Buile Suibhne', in The Art of Translation: Voices from the Field, ed. by Rosanna Warren (Northeastern University Press: Boston, 1989), p.15. The essay also appeared in Poetry Ireland Review 25 (1989), 95-100.

17. Heaney, 'Earning a Rhyme', pp.15-16.

18. Heaney, 'Earning a Rhyme', p.17.

19. In a 1985 thesis on Heaney's early work, Ann Valentine Cobb highlights other striking allusions, such as 'Only your hawk eye / would know me now / who was once the mould of form in Dal Araidhe', echoing Ophelia's 'mould of form' in Hamlet. Perhaps Heaney is thinking, too, about Hamlet's knowing 'a hawk from a handsaw' here. Cobb's research appears to be based on the typed version of the notebook draft acquired by The National Library in 1986.

20. O'Keeffe, p. 131. Further references to this edition are given in parentheses in the text. Here and elsewhere, I provide the original Irish only where O'Keeffe diverges from it significantly, or the wording is relevant to my argument.

21. Flann O'Brien's At Swim-Two-Birds (1939), which Heaney describes in the introduction to Sweeney Astray as giving Suibhne 'a second life, as hilarious as it was melancholy' (p.vii), parodies the use of nominal identification in the original text.

22. Heaney, 'Earning a Rhyme', p.17.

23. Heaney, 'Earning a Rhyme', p.20.

24. Carson, 'Escaping from Limbo', p.143.

25. In the notebook, the word 'wood' has been crossed out and replaced with 'plantation', suggesting a deliberate eschewal of O'Keeffe's term.

26. Carson, p.143.

27. A note in the margin of the notebook draft - 'NOTE PUN ON BENN' - indicates Heaney was aware of it.

28. Carson, p.147.

29. Downum, pp.82-3.

30. Trevor Joyce, The Poems of Sweeny, Peregrine: a working of the corrupt Irish text (Dublin: New Writers' Press, 1976). His 'Note on the Text' aligns his approach with Clarence Mangan's 'inventive translations'. 
31. Carson, p.145.

32. Donoghue, p.28.

33. See, for example, O'Keeffe, p.xxxiv, and James Carney, Studies in Irish Literature and History (Dublin: Dublin Institute for Advanced Studies, 1955), pp.136-7.

34. Nora K. Chadwick, 'Geilt', Scottish Gaelic Studies 5 (1942), 106-53 (pp.116-7).

35. For more on this, see 'Wild Goose Chase' in Rebecca Solnit's Book of Migrations, pp.184-196, which begins 'In books, however, the Irish were always turning into birds', and catalogues many popular examples, including Suibhne/Sweeney.

36. Donoghue, p.28.

37. Kerrigan, 'Ulster Ovids', The Chosen Ground, ed. by Neil Corcoran (Bridgend: Seren Books, 1992), p.254.

38. Randy Brandes and Seamus Heaney, 'Seamus Heaney: An Interview', Salmagundi, 80 (1988): 4-21, pp.11-12.

39. Brandes and Heaney, p.12.

40. Seamus Heaney, 'Envies and Identifications: Dante and the Modern Poet', Irish University Review 15.1 (1985), 5-19, p.5.

41. Donoghue, p.28. 